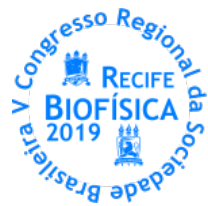

\title{
APLICAÇÃO DA INATIVAÇÃO FOTODINÂMICA ANTIMICROBIANA EM CEPA MULTIRRESISTENTE ISOLADA DA MASTITE BUBALINA
}

\author{
Evanísia Assis Góes de Araújo ${ }^{1 *}$, Claudio Henrique Rodrigues ${ }^{2}$, Thiago Pajeú Nascimento ${ }^{3}$, Adriana Fontes ${ }^{4}$, Juliana \\ Falcão ${ }^{5}$, Goreti Carvalho Pereira ${ }^{6}$, Ana Lúcia Figueiredo Porto ${ }^{3}$, Beate Saegesser Santos ${ }^{2}$
}

${ }^{1}$ Programa de Pós-Graduação em Ciência de Materiais, UFPE, ${ }^{2}$ Departamento de Ciências Farmacêuticas, UFPE, ${ }^{3}$ Departamento de Morfologia e Fisiologia Animal, UFRPE, ${ }^{4}$ Departamento de Biofísica e Radiobiologia, UFPE, ${ }^{5}$ Centro de Educação e Saúde, UFCG, ${ }^{6}$ Departamento de Química Fundamental, UFPE

*evanisia@outlook.com

\section{RESUMO}

A preocupação com a resistência bacteriana vem preocupando pesquisadores de diversas áreas ao longo dos anos, que têm indicado novas propostas para tratamentos alternativos na inativação microbiana, que sejam menos invasivas e mais promissoras para sua erradicação. Uma destas alternativas está relacionada com inativação fotodinâmica (IFD), a qual combina uso de um fotossensibilizador, irradiação com uma fonte de luz de baixa potência e o oxigênio molecular. Essa ativação leva à geração de espécies reativas de oxigênio (EROs) que apresentam toxicidade celular induzindo a destruição de proteínas, lipídios e ácidos desoxirribonucleicos, culminando com a morte bacteriana. A mastite consiste numa doença infecciosa causada pela invasão de microrganismos pelo canal da teta e que se prossegue à área cisterna da glândula responsável pela passagem do leite, causando a redução na capacidade produtora do rebanho. Observa-se que o Staphylococcus aureus é um dos microrganismos comuns observados em mastite bovina e bubalina. Neste sentido, o objetivo central deste estudo foi investigar o uso da IFD frente a uma cepa de Staphylococcus aureus, isolada de mastite bubalina e que apresenta alta resistência a antibióticos comuns. Foi utilizada uma cepa multirresistente de $S$. aureus isolada de mastite bubalina. 0 microrganismo foi crescido previamente em caldo TSB sendo inoculado em microplaca de 96 poços contendo meio caldo Müller Hinton e o fotossensibilizador azul de metileno (AM) na concentração de $15 \mu \mathrm{mol} . \mathrm{L}^{-1}$ por $10 \mathrm{~min}$ e irradiados na região do vermelho $(\lambda=660 \mathrm{~nm})$ com dose $90 \mathrm{~J} / \mathrm{cm}^{2}$, por $5 \mathrm{~min}$. Em seguida a microplaca foi incubada em estufa bacteriológica à $37^{\circ} \mathrm{C}$ por $24 \mathrm{~h}$. A viabilidade bacteriana foi observada através de contagem em microplaca, bem como através de análise qualitativa utilizando o reagente resazurin. A capacidade de produção de EROs do $A M$ foi avaliada através de método espectrofotométrico. Todos os experimentos foram realizados em triplicata. A análise dos dados mostrou que o AM apresenta uma produção de EROs de eficiência de $86 \%$ nas condições estudadas em acordo com resultados observados na literatura (entre $70-80 \%$ ). 0 ensaio IFD utilizando o $A M$ provocou uma inativação média de $59,73 \pm 0,6$ do $S$. aureus, resultado que apresenta grande potencial para que, com a otimização das condições experimentais (dose de luz, tempo de incubação, concentração do $\mathrm{AM}$ ) através de ensaios quimiométricos, uma inativação máxima possa ser alcançada. Vale ressaltar que a cepa de $S$. aureus isolada de mastite bubalina utilizada nesse estudo possui uma alta resistência aos antibióticos de uso comum: penicilina, amoxilina, cefquinoma, cefalosporina, ciprofloxacina, enrofloxacina, eritromicina, florfenicol, gentamicina, cefalotina, tetraciclina, estreptomicina, norfloxacina, estreptomicina, ceftriaxona, nitrofurantoína, doxiciclina, cefalexina, sulfametoxazol+trimetoprima e tetraciclina+neomicina+bacitracina. Essa resistência não só diminui a eficácia do tratamento convencional, mas também, pode estimular a produção de biofilme. Portanto, este estudo preliminar levou a uma redução considerável do microrganismo testado, demonstrando o potencial desta técnica para tratamento alternativo de infecções em bovinos e bubalinos. 